$($ Jpn. J. Hosp. Pharmi

$\left(\begin{array}{ccc}0 & \\ 265 & 5(0) & -509(2000)\end{array}\right)$

高速液体クロマトグラフィーによる新生児血漿中パニペネム濃度の測定

国分秀也 ${ }^{*} \dagger^{1}$ ，木村利美 $\dagger^{1}$ ，村瀬勢津子 $\dagger^{1}$ ，島田慈彦 $\dagger^{1}$ ，久保博昭 $\dagger^{2}$ ， 松本真紀 $\dagger^{3}$, 野渡正彦 $\dagger^{3}$, 松浦信夫 $\dagger^{3}$

北里大学病院薬夙部 $\left.\right|^{1}$

北里大学薬学部到

北里大学医学部小児科 ${ }^{3}$

\title{
Determination of Plasma Panipenem Concentration in Neonates by High-Performance Liquid Chromatography
}

\author{
HIDEYA KOKUBUN ${ }^{*} \dagger^{1}$, TOSHIMI KIMURA $\dagger^{1}$, SETSUKO MURASE $\dagger^{1}$, SHIGEHIKO SHIMADA $\dagger^{1}$, \\ HIROAKI KUBO $\dagger^{2}$, MAKI MATSUMOTO $\dagger^{3}$, MASAHIKO NOWATARI $\dagger^{3}$ and NOBUO MATSUURA $\dagger^{3}$ \\ Department of Pharmacy, Kitasato University Hospital $\dagger^{1}$ \\ School of Pharmaceutical Sciences, Kitasato University $\dagger^{2}$ \\ Department of Pediatrics, Kitasato University School of Medicine $\uparrow^{3}$
}

$\left(\begin{array}{l}\text { Received February 1, 2000 } \\ \text { Accepted July 7, } 2000\end{array}\right)$

A simple and fast determination of plasma panipenem (PAPM) in extremely low birth weight infants was established using reversed phase high-performance liquid chromatography. Solutions of $35 \%$ methanol ( $\mathrm{pH} 5.8$ ), including $5 \mathrm{mM} \mathrm{NaH}_{2} \mathrm{PO}_{4}$ and $5 \mathrm{mM}$ sodium dodecylsulfate, were used for the mobile phase. The flow rate was $0.8 \mathrm{~mL} / \mathrm{min}$. UV detection was carried out at 300 $\mathrm{nm}$. The pretreatment method was as follows : $200 \mathrm{mM} 3$-[morpholino] propansulfonic acid solution was added to the plasma as a stabilizer. It was then deproteinized with methanol. The calibration curve was linear in a range from $6.25 \mu \mathrm{g} / \mathrm{mL}$ to $100 \mu \mathrm{g} / \mathrm{mL}$. The recovery rate from known concentration samples of PAPM was $98.4 \%$. The within-run and day-to-day variations were below $2.5 \%$ and $2.7 \%$, respectively. The PAPM concentrations in the plasma were determined in five infants. In immature patients, an extension of the half-life was also observed.

Key words - panipenem, neonate, infection, carbenin, high-performance liquid chromatography

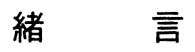

カルベニン®（パニペネム/ベタミプロン，以

下, PAPM/BP と略す）は，グラム陽性・陰性菌

+1-3 神奈川県相模原市北里1-15-1；1-15-1, Kitasato, Sagamihara-shi, Kanagawa, 228-8555 Japan
に対し幅広い抗菌活性を有するカルバペネム系の 抗生物質であり，現在，広く臨床で使用されてい る.小児科領域においては,尿路感染症や髄膜炎， 敗血症等の重症感染症の治療に用いられ, 免疫能 が不十分な超低出生体重児の重症感染症において は, 重要な役割を果たしている。しかしながら, 
小児に対する適応が認められているものの，新生 児での至適投与量の検討はなされておらず，安全 性が確立されていないのが現状である。そこでわ れわれは，新生児における PAPM/BP の至適投与 量を設定することを目的として血漿中 PAPM 濃 度測定を試みた。

これまでに報告されている PAPMの濃度測定 法 ${ }^{1)}$ 行ったところ, PAPM が幾何異性体を持つ ためにチャート上ピークが 2 本となり新生児の極 微量の検体では低濃度まで定量することが出来な かった

そこで，幾何異性体を分離せずに，UV 検出器 を用い，イオン対逆相クロマトグラフィーによる 簡便な微量定量法を確立し，さらに数症例の新生 児の PAPM 体内動態を検討したので報告する。

\section{実 験 の 部}

\section{1．標準品と試薬}

PAPM 原末 (Lot. No. 227) は三共株式会社より 譲渡を受け，200mM 3-[N-morpholino] propanesulfonic acid（MOPS）液に溶解したものを標準液 とした.MOPS はシグマ社のものを用いた。

移動相に用いた溶媒とイオンペア試薬は, 高速 液体クロマトグラフ用で, その他の有機溶媒およ び試薬は，すべて試薬特級を用いた。

\section{2 . 装置}

高速液体クロマトグラフ（HPLC）は，Multisolvent Delivery System 600 （Waters）を用いた。検 出器は, UV-970（日本分光）使用し, 検出波長 は300nm に設定した。

カラムは, 細孔径 $150 \AA$ 球状シリカゲルにオク タデシル基を化学結合した充填劑（微粒子直径 5 $\mu \mathrm{m})$ を使用している逆相系カラム Inertsil ODS2 （4.6×150mm, GLScience）を用いた.

\section{3. 移動相}

$5 \mathrm{mM} \mathrm{NaH}_{2} \mathrm{PO}_{4}$ と $5 \mathrm{mM}$ ドデシル硫酸ナトリ ウムを含を $35 \%$ メタール（pH5.8）を用いた。 なお，流速は $0.8 \mathrm{~mL} / \mathrm{min}$ とした。

\section{4. 前処理法}

PAPM は非常に不安定であるため, 採血後, 微 量血漿 $10 \mu \mathrm{L}$ に対し，ただちに安定剤である200 mM MOPS $10 \mu \mathrm{L}$ を加えた。次に，除蛋白凬とし てメタノール100 $\mu \mathrm{L}$ を加えボルテックスミキ サーで混和し，析出した蛋白質を 5 分間 12,000 rpm で遠沈させ，その上清を HPLCの試料とし た.また，操作は常に水冷下で行った。

\section{5. 血漿中 PAPM の安定性}

$\mathrm{PAPM}$ が $25 \mu \mathrm{g} / \mathrm{mL}$ となるように添加調製され たヒト血漿と $200 \mathrm{mM}$ MOPS を $1 ： 1$ の割合で混 合し, 室温 $\left(+23^{\circ} \mathrm{C}\right)$, 冷所 $\left(+4{ }^{\circ} \mathrm{C}\right)$ および凍結 $\left(-30^{\circ} \mathrm{C}\right)$ に保存して経時的に残存率を測定した。

\section{6. 新生児の血中濃度測定}

北里大学病院 NICU 入院中にPAPM/BP 10 $20 \mathrm{mg} / \mathrm{kg} /$ 回, 1 日 2 回, 輸注ポンプにて治療が 行われ，両親からの同意を得た新生児 5 例を対象 とした。採血は，原則として投与開始 3 日目の投 与直前, 1 時間後, 2 時間後, 6 時間後とした.

\section{結果および考察}

\section{1. 分離条件の検討}

移動相は，25\%のメタノールを含む $1 \mathrm{mM}, 5$ $\mathrm{mM}$ および $10 \mathrm{mM} \mathrm{NaH}_{2} \mathrm{PO}_{4}$ とイオンペア試薬の $5 \mathrm{mM}$ デカンスルホン酸ナトリウム, $5 \mathrm{mM}$ ウン デカンスルホン酸ナトリウムおよび $5 \mathrm{mM}$ ドデカ ンスルホン酸ナトリウムのそれぞれの組み合わせ について検討した。 また，それぞれの移動相に対 して, 除蛋白浏としてメタノール゙あるいはアセ トニトリル2にについて検討した。その結果，除蛋 白㣚はメタノールで $5 \mathrm{mM}$ および $10 \mathrm{mM} \mathrm{NaH}_{2}$ $\mathrm{PO}_{4}$ と $5 \mathrm{mM}$ ウンデカンスルホン酸ナトリウムの 組み合わせ, $10 \mathrm{mM} \mathrm{NaH}_{2} \mathrm{PO}_{4}$ と $5 \mathrm{mM}$ ドデカン スルホン酸ナトリウムの組み合わせが最も良好な 1 本のピークを示した。 また，除蛋白㓮をアセ卜 ニトリルにした時，すべての組み合わせにおいて 幾何異性体が分離した。したがって，除蛋白戍を メタノールとし，上記の 3 つの組み合わせの移動 相を用い，新生児の血漿中 PAPM 濃度測定を 
行った.

しかし，新生児の血漿中 PAPM 濃度を測定す ると正常血漿にはない夾雑物が PAPM とほぼ同 じ位置に検出された。 そこで，その夾雑物と PAPM を分離するために，イオンペア試薬として PAPM の保持時間がさらに長くなることが予測さ れる $5 \mathrm{mM}$ ドデシル硫酸ナトリウムを用い, 緩衝 液と除蛋白剤は同じもので移動相を $25 \%, 30 \% お ~$ よび35\%メタノールについて検討したとこ ろ, 25\%および30\%メタノールの場合, PAPMの

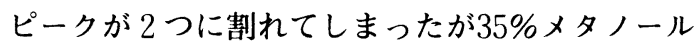
を用いた場合，夾雑物の影響もなく，1 本の良好 なピークになり, retention timeも 5 分間と良好で あった（Fig. 1)。よって，最終的にイオンペア として $5 \mathrm{mM}$ ドデシル硫酸ナトリウム, 緩衝液と して $5 \mathrm{mM} \mathrm{NaH}_{2} \mathrm{PO}_{4}$ および除蛋白剤としてメタ ノールを用い新生児の PAPM の体内動態を検討 した.

\section{2. 検量線の作成}

PAPM 原末を $200 \mathrm{mM}$ MOPS 液に溶解し， 6.25

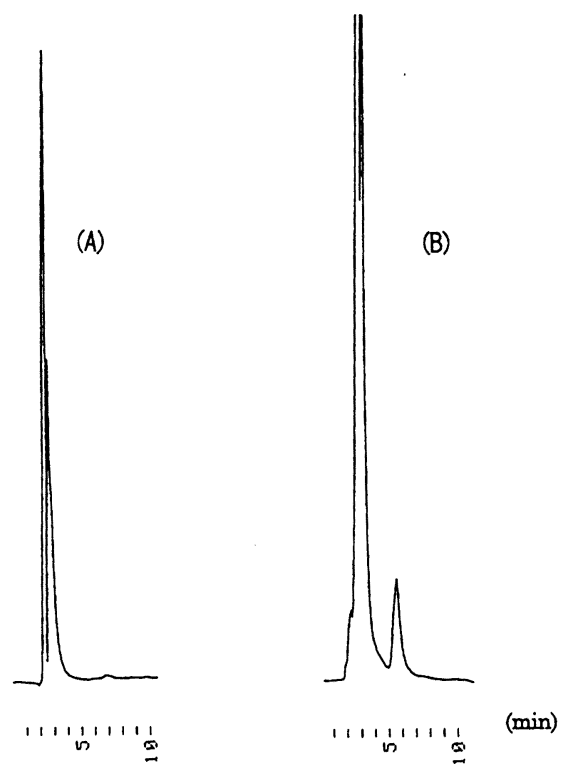

Fig. 1. Chromatograms Obtained from Control Plasma (A), and Newborn Plasma (B) $\mu \mathrm{g} / \mathrm{mL}, 12.50 \mu \mathrm{g} / \mathrm{mL}, 25.00 \mu \mathrm{g} / \mathrm{mL}, 50.00$ $\mu \mathrm{g} / \mathrm{mL}$ および $100.00 \mu \mathrm{g} / \mathrm{mL}$ の標準液を作成した

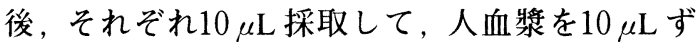
つ添加する。次に, 定量操作に従って処理し, 検 量線を作成した。横軸にPAPM 濃度を，縦軸に PAPMのピーク高さをプロットした検量線を Fig. 2 に示した．検量線は原点を通る良好な直線 関係を示し，相関係数は1.000であった。検出感 度は, $\mathrm{S} / \mathrm{N}=3$ で, PAPM 濃度は $0.5 \mu \mathrm{g} / \mathrm{mL}$ であ り，新生児の極微量血漿 $(10 \mu \mathrm{L})$ に対しても低 濃度までの測定を可能とした。

3. 再現性および回収率

血漿中 PAPM 濃度として, 低濃度 $(6.25 \mu \mathrm{g})$ $\mathrm{mL})$ ，中濃度 $(50 \mu \mathrm{g} / \mathrm{mL})$ および高濃度 $(100 \mu \mathrm{g} /$

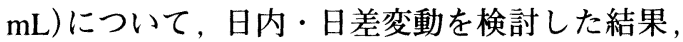
各濃度とも日内変動は2.5\%以下, 日差変動は 2.7\%以下と良好な結果が得られた（Table 1$)$.

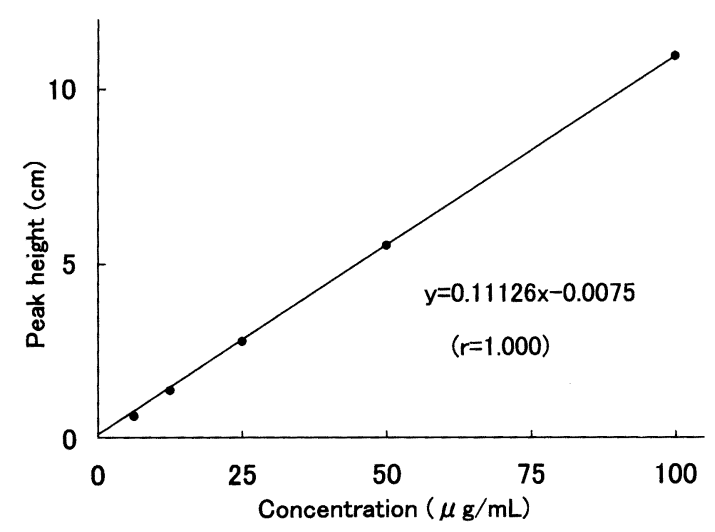

Fig. 2. Calibration Curve of Panipenem in Newborn Plasm

Table 1. Reproducibility for Analyses

\begin{tabular}{ccc}
\hline $\begin{array}{c}\text { Concentration } \\
(\mu \mathrm{g} / \mathrm{mL})\end{array}$ & $\begin{array}{c}\text { Within-run } \\
\text { C.V.\%, }(\mathrm{n}=10)\end{array}$ & $\begin{array}{c}\text { Between-run } \\
\text { C.V.\%, }(\mathrm{n}=5)\end{array}$ \\
\hline 6.25 & 2.5 & 2.4 \\
50 & 1.4 & 2.7 \\
100 & 1.6 & 1.7 \\
\hline
\end{tabular}


また, 絶対検量線により回収率を求めた結果, 98.4\%と良好であった。

\section{4. 試料の安定性}

室温保存では残存力価が 6 時間で $95.5 \%$ まで低 下したが，冷所保存では 6 時間，凍結保存では 4 日間まで力価低下は認められなかった。これらの 成績から PAPM 検体は凍結保存とし, 保存後 4 日間は安定であると考えられた（Table 2).

\section{5．新生児の血中 PAPM 濃度測定}

PAPM を使用している新生児 5 例に対して, 血 中濃度測定を行った（Table 3，Fig. 3)。その 結果, 在胎週数が最も短かった症例(1)において半 減期が最も長く, 健常成人男性の平均半減期（約 70 分 $)^{3)}$ や腎機能正常な小児の平均半減期（約60 分) ${ }^{4)} 2$ 倍以上であった。その他の症例におい ても在胎週数が短いほど半減期が長くなる傾向に
あった。このことは, PAPM が腎蔵より $80 \%$ 排泄 され3)，腎機能低下が高度となるほど PAPM 半減 期が延長する5ことと，系球体ろ過率が在胎週数

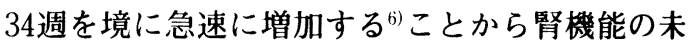
熟により PAPMの排泄が遅延していたと考えら れた。その他の症例においても在胎週数が短いほ ど半減期が延長する傾向にあった。

また, Fig. 3 において, 投与開始 1 時間値の血 中濃度がほぼ消失相の直線の延長上であることか ら, PAPMの分布は，成人と同様に新生児におい ても 1 時間以内に終了しているものと考えられ た.

今後, 症例を積み重ね新生児における PAPM の至適投与量を決定したい.

謝辞 本研究に際し，パニペネム原末を提供してい ただいた三共株式会社に心より感謝いたします。

Table 2. Stabilities of Panipenam in Human Plasma

The human plasma and the solution of $25 \mu \mathrm{g} / \mathrm{mL}$ PAPM in the stabilizer were mixed in the ratio of $1: 1$, and stored at room temperature $\left(+23^{\circ} \mathrm{C}\right)$, in a cold place $\left(+4^{\circ} \mathrm{C}\right)$ and froze $\left(-30^{\circ} \mathrm{C}\right)$.

\begin{tabular}{|c|c|c|c|c|c|c|c|c|}
\hline \multirow{2}{*}{$\begin{array}{l}\text { Temp } \\
\left({ }^{\circ} \mathrm{C}\right)\end{array}$} & \multicolumn{8}{|c|}{ Time(hrs) } \\
\hline & 0 & 2 & 6 & 24 & 48 & 96 & 216 & 408 \\
\hline 23 & $100(\%)$ & $101.1 \pm 2.1$ & $95.5 \pm 5.0$ & $77.1 \pm 6.8$ & - & - & - & - \\
\hline 4 & $100(\%)$ & $101.6 \pm 2.9$ & $103.0 \pm 6.3$ & $99.3 \pm 0.4$ & $97.3 \pm 4.0$ & $87.2 \pm 9.1$ & - & - \\
\hline-30 & $100(\%)$ & $102.6 \pm 3.6$ & $101.6 \pm 4.4$ & $102.7 \pm 5.1$ & $101.9 \pm 2.7$ & $104.6 \pm 2.3$ & $98.9 \pm 5.8$ & $95.5 \pm 2.9$ \\
\hline
\end{tabular}

Table 3. Results of Determination of Plasma Panipenem Concentration in Neonates

\begin{tabular}{|c|c|c|c|c|c|c|c|c|c|c|c|}
\hline \multirow[t]{2}{*}{ case } & \multirow[t]{2}{*}{ sex } & \multicolumn{2}{|c|}{ gestational postconceptional } & \multirow{2}{*}{$\begin{array}{c}\text { bodyweight } \\
\text { (g) }\end{array}$} & \multirow{2}{*}{$\begin{array}{c}\text { PAPM dosage } \\
\text { (mg/kg, daily times) }\end{array}$} & \multicolumn{5}{|c|}{ concentration $(\mu \mathrm{g} / \mathrm{mL})$} & \multirow{2}{*}{$\begin{array}{l}\mathrm{t}_{1 / 2} \\
(\mathrm{hr})\end{array}$} \\
\hline & & age & age & & & trough & $1 \mathrm{hr}$ & $2 \mathrm{hr}$ & $4 \mathrm{hr}$ & $6 \mathrm{hr}$ & \\
\hline (1) & $F$ & $24 w 6 d$ & $25 w 4 d$ & 640 & $15.6 \times 2$ & 4.7 & 29.5 & & 13.8 & & 2.8 \\
\hline (2) & $F$ & $29 w 2 d$ & $31 w 0 d$ & 770 & $15.6 \times 2$ & 1.9 & 32.1 & 23.4 & & 8.4 & 2.6 \\
\hline (3) & $\mathrm{F}$ & $30 w 6 d$ & $33 w 3 d$ & 1272 & $18.9 \times 3$ & 7.4 & 37.1 & 29.0 & 15.8 & & 2.6 \\
\hline (4) & $\mathbf{F}$ & $35 w 1 d$ & $37 w 5 d$ & 1772 & $25.4 \times 2$ & 2.0 & 39.0 & 27.3 & & 7.4 & 2.1 \\
\hline (5) & M & $40 w 3 d$ & $42 w 4 d$ & 3218 & $15.5 \times 2$ & 1.2 & 27.6 & 17.5 & & 4.0 & 1.7 \\
\hline
\end{tabular}




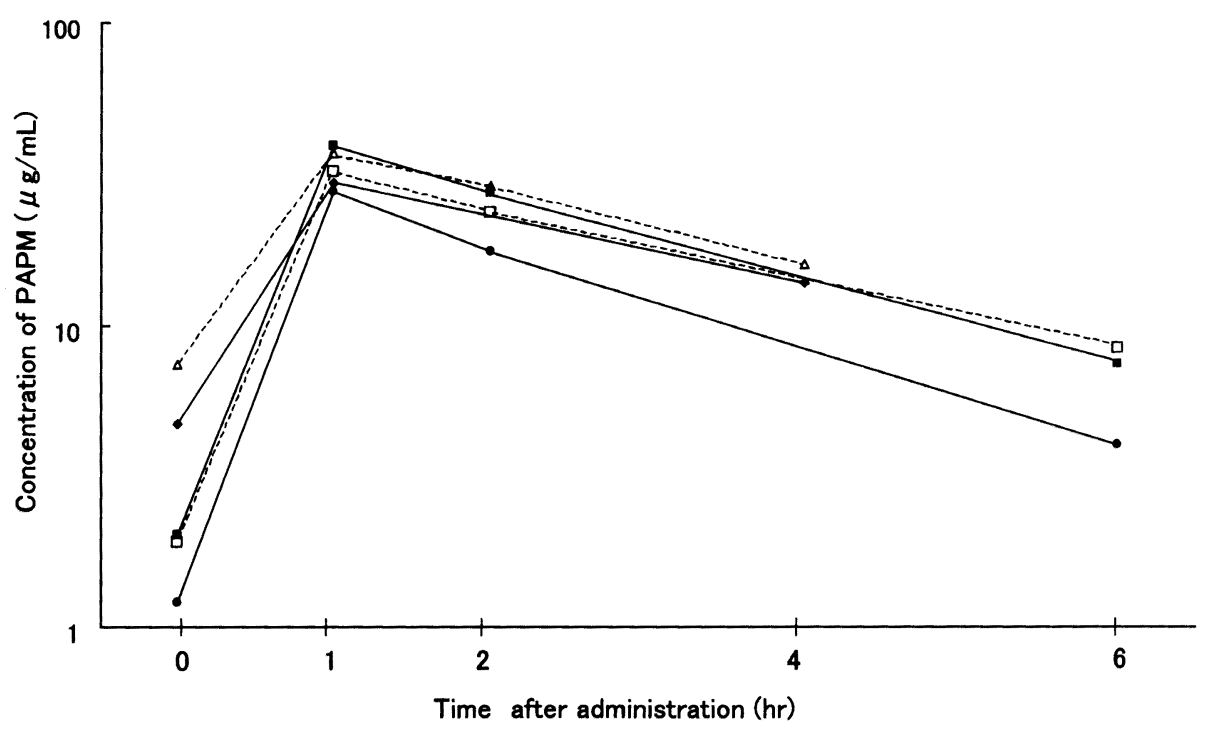

Fig. 3. The Time Course of Concentration in Neonates

Back Ground :

( ) gestational age ; 24 weeks, bodyweight ; $640 \mathrm{~g}$, PAPM dosage ; $15.6 \mathrm{mg} / \mathrm{kg}$ two times a day

( $\square$ ) gestational age ; 29 weeks, bodyweight ; $770 \mathrm{~g}$, PAPM dosage ; $15.6 \mathrm{mg} / \mathrm{kg}$ two times a day

$(\triangle)$ gestational age ; 30 weeks, bodyweight ; $1272 \mathrm{~g}$, PAPM dosage ; $18.9 \mathrm{mg}$ / $\mathrm{kg}$ three times a day

( $\square$ ) gestational age ; 35 weeks, bodyweight ; $1772 \mathrm{~g}$, PAPM dosage ; $25.4 \mathrm{mg} /$ $\mathrm{kg}$ two times a day

(O) gestational age ; 40 weeks, bodyweight ; $3218 \mathrm{~g}$, PAPM dosage ; $15.5 \mathrm{mg}$ / $\mathrm{kg}$ two times a day

\section{引用文献}

1）久岡正史，長沼英夫，高萩英邦，川原幸則，山 崎泰志, Chemotherapy, 39, 197-205 (1991).

2) 久保博昭, 月刊薬事, 26, 145-150 (1984).

3) 中島光好，植松俊彦，長沼英夫，久岡正史，川 原幸則，金丸光隆，田島政三，Chemotherapy， 39, 242-264 (1991).

4) 藤井良知, 阿部敏明, 田島剛，寺島周，目黒英 典，森淳夫，中澤進，佐藤肇，新納憲司，砂川 慶介，岩田敏，秋田博伸，佐藤吉壮，豊永義 清, 瀬尾究, 河村研一, 堀誠, 久野邦義, 岩井 直一, 種田陽一, 中村はるひ, 桜井寛, 伊藤正 寛, 神谷斉, 庵原俊昭, 西村忠史, 田吹和雄, 高木通生，青木繁幸，小林裕，春田恒和，古川
正強, 岡本喬, 黒田泰弘, 武田英二, 倉繁隆 信, 森田秀雄, 松田博, 貴田嘉一, 藤澤由樹, 辻芳郎, 林克敏, 冨増邦夫, 森剛一, 遠矢芳 一, 中下誠郎, 権藤泉, 小林伸雄, 本廣孝, 高 城信彦, 今井昌一, 荒木久昭, 林真夫, 小野栄 一郎, 橋本武夫, 久保田薰, 石本耕治, 西山 亨, 久田直樹, 富永薰, 安岡盟, 鈴木和重, 田 中耕一, 藤本保, Jpn. J. Antibio., 45, 208-225 (1992).

5) 青木信樹, 薄田芳丸, 甲田豊, 高沢哲也, 若林 伸人, 林静一, 新田功, 本間千鶴子, 渡辺京 子, Chemotherapy, 39, 372-384(1991).

6) 伊藤克巳, 白髮宏司, 周産期医学, 26, 757-761 (1996). 